U.S. Department of the Interior U.S. Geological Survey

\title{
Lahar Hazards at Casita and San Cristóbal Volcanoes, Nicaragua
}

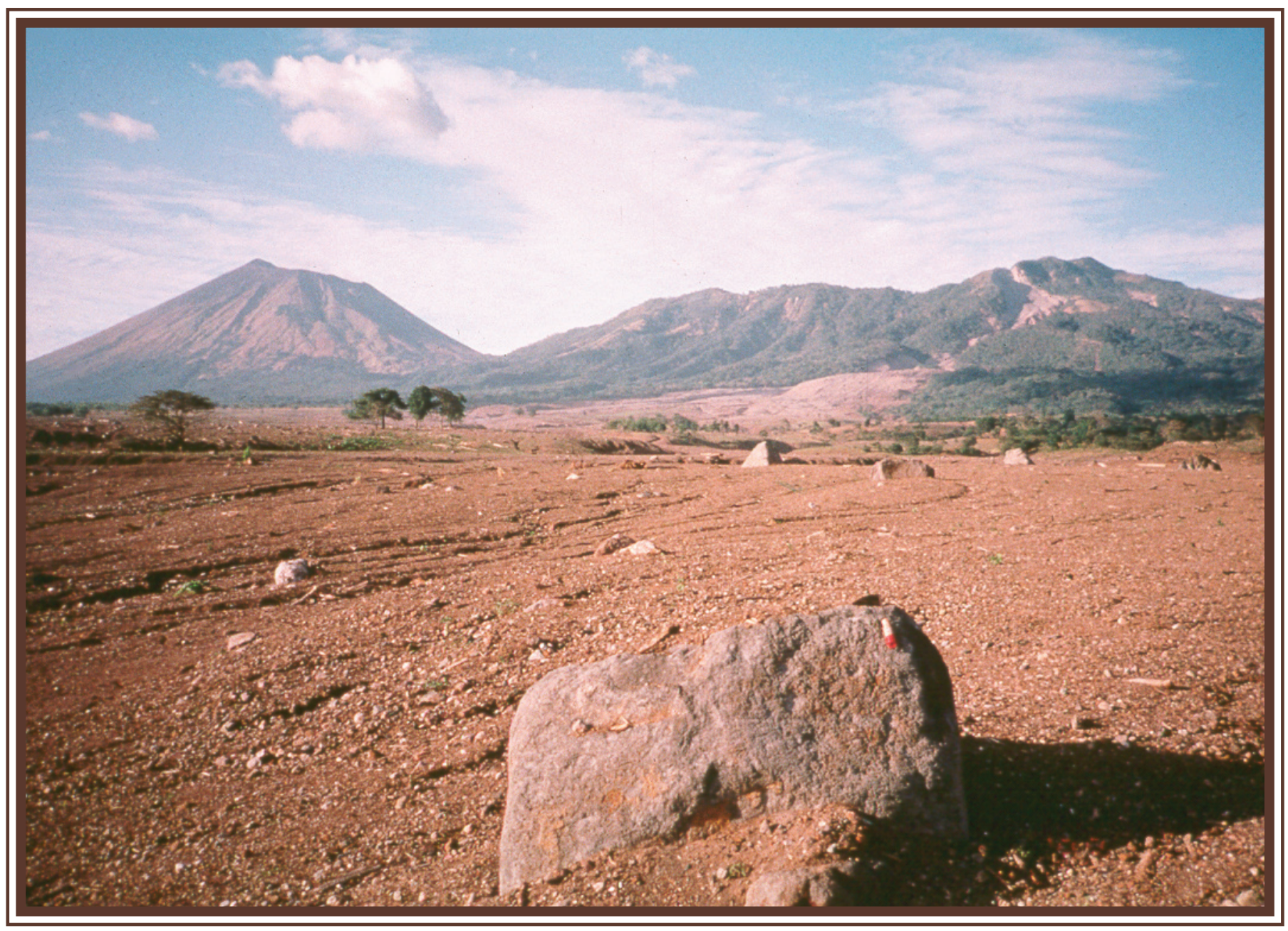

Open-File Report 01-468 
Cover photograph:

Casita (right) and San Cristóbal (left) volcnoes from the south showing the October 30, 1998, Casita debris flows in the foreground (photograph by K.M. Scott). 


\section{Lahar Hazards at Casita and San Cristóbal Volcanoes, Nicaragua}

By J.W. Vallance, S.P. Schilling, G. Devoli, M.E. Reid, M.M. Howell, and D.L. Brien

U.S. GEOLOGICAL SURVEY

Open-File Report 01-468 


\section{U.S. DEPARTMENT OF THE INTERIOR Gale Norton, Secretary}

U.S. GEOLOGICAL SURVEY

Charles G. Groat, Director

Any use of trade product or firm names is for descriptive purposes only and does no imply endorsement by the U.S. Government.

For additional information write to:

Copies of this report can be purchased from:

Scientist-in-Charge

U.S. Geological Survey

1300 SE Cardinal Court, Suite 100

Vancouver, WA 98685

(360) $993-8900$

FAX: (360) 993-8980
U.S. Geological Survey

Information Services

P.O. Box 25286

Denver, CO 80225

(303) 202-4210 


\section{CONTENTS}

Introduction. . ... $\square \quad 1$

Debris Avalanches, Landslides, and Lahars . . . . . . . . . . . . . . . . . 5

Genesis of Slope Failures and Lahars at Casita during Hurricane Mitch . . . . . . . . . . . . . 5

Observations .. $\square \quad 5$

Genesis and downstream behavior $\ldots \ldots \ldots \ldots \ldots \ldots \ldots \ldots$

Genesis of Lahars and Floods at San Cristóbal during Hurricane Mitch . . . . . . . . . . . . 7

Future Landslides and Lahars at Casita Volcano . . . . . . . . . . . . . . . . . . 8

Future Landslides and Lahars at San Cristóbal Volcano. . . . . . . . . . . . . . . 8

Priliminary 3-D slope-stability assessment of Casita and San Cristóbal Volcanoes . . . . . . . . 9

Lahar-Hazard-Zonation at Casita and San Cristóbal Volcanoes . . . . . . . . . . . . . . . 10

Lahar-hazard Zonation Map for Casita Volcano . . . . . . . . . . . . . . . . . 11

Lahar-hazard Zonation Map for San Cristóbal Volcano . . . . . . . . . . . . . . . . . 13

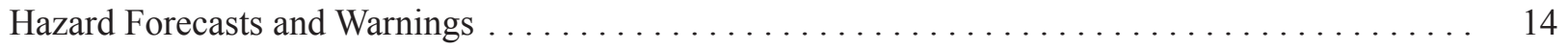

Protecting Communities and Citizens from Lahar Hazards . . . . . . . . . . . . . . . 14

References...... $\square \quad 15$

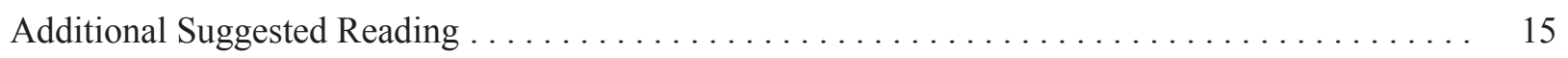

End Notes ...... $\square \quad 16$

\section{PLATES [In pocket]}

1. Surficial Geologic Map of the South Side of Casita Volcano and of San Cristóbal Volcano, Nicaragua,Showing Distribution of the AD 1998 and 2000 Debris-Flow and Flood deposits

2. Lahar hazards for Casita volcano, Nicaragua

3. Lahar hazards for San Cristóbal volcano, Nicaragua 


\section{FIGURES}

1. Locations of major cities and significant Quaternary volcanoes in Nicaragua including Casita volcano and schematic map showing the areal extent of the 1998 debris flow . . . . . 1

2. Shaded topographic map showing the edifice of Casita volcano and the distribution of fumarolic zones and areas of hydrothermal alteration $\ldots \ldots \ldots \ldots \ldots \ldots \ldots \ldots \ldots \ldots \ldots \ldots \ldots$

3. Aerial photograph of the upper southern slopes of Casita volcano showing the 1998 debris flow scarp and numerous smaller scarps generated by Hurricane Mitch . . . . . . . 3

4. Topographic map and two cross-sections for the Casita, Nicaragua debris flow of $1998 \ldots \ldots \quad 4$

5. Photograph showing the scarp of the avalanche that generated the October 30, 1998

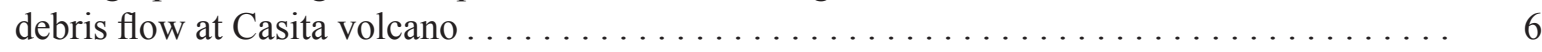

6. Photograph showing the edifice of San Cristóbal volcano from the northeast $\ldots \ldots \ldots \ldots .8$

7. Shaded topographic map of San Cristóbal and Casita volcanoes showing predicted 3-D slope stability using scenario 1, uniform relatively strong rocks in the San Cristóbal edifice and uniform moderately weak rocks in the Casita edifice $\ldots \ldots \ldots \ldots \ldots$

8. Shaded topographic map of San Cristóbal and Casita volcanoes showing predicted 3-D slope stability using scenario 2 , assuming three limited, highly altered, weak zones in the Casita edifice. . . . . . . . . . . . . . . . . . . . . . . . . . .

9. Shaded topographic map of San Cristóbal and Casita volcanoes showing predicted 3-D slope stability using scenario 3, assuming an extensive, highly altered, weak zone in the Casita edifice 


\title{
Lahar Hazards at Casita and San Cristóbal Volcanoes, Nicaragua
}

\author{
By J.W. Vallance', S.P. Schilling', G. Devoli ${ }^{3}$, M.E. Reid ${ }^{2}$, M.M. Howell', \\ and D.L. Brien ${ }^{2}$
}

\section{INTRODUCTION}

Casita and San Cristóbal volcanoes are part of a volcano complex situated at the eastern end of the Cordillera de los Maribios (figure 1). Other centers of volcanism in the complex include El Chonco, Cerro Moyotepe, and La Pelona (plate 1). At $1745 \mathrm{~m}$, San Cristóbal is the highest and only historically active volcano of the complex. The volcano's crater is 500 to 600 $\mathrm{m}$ across and elongate east to west; its western rim is more than $100 \mathrm{~m}$ higher than its eastern rim [1]. The conical volcano is both steep and symmetrical. El Chonco, which lies west of San Cristóbal, is crudely conical but has been deeply dissected by streams. Cerro Moyotepe to the northeast of San Cristóbal is even more deeply incised by erosion than El Chonco, and its crater is breached by erosion. Casita volcano, about $5 \mathrm{~km}$ east of San Cristóbal volcano, comprises a broad ridge like form, elongate along an eastwest axis, that is deeply dissected. Nested along the ridge are two craters. The younger one, $\mathrm{La}$ Ollada crater, truncates an older smaller crater to the east near Casita's summit (1430 m). La Ollada crater is about $1 \mathrm{~km}$ across and $100 \mathrm{~m}$ deep. Numerous small fumarole fields occur near the summit of Casita and on nearby slopes outside of the craters (figure 2). Casita volcano overlaps

${ }^{1}$ U.S. Geological Survey, 1300 SE Cardinal Court, Suite 100, Vancouver, Washington 98683, USA

2 U.S. Geological Survey, 345 Middlefield Road, Menlo Park, California 94025, USA

3 Instituto Territoriales Nicaragüense Regionale (INETER), Managua, Nicaragua the 3-km-wide crater of La Pelona to the east. Stream erosion has deeply incised the slopes of La Pelona, and it is likely the oldest center of the Casita-San Cristóbal volcano complex [1].

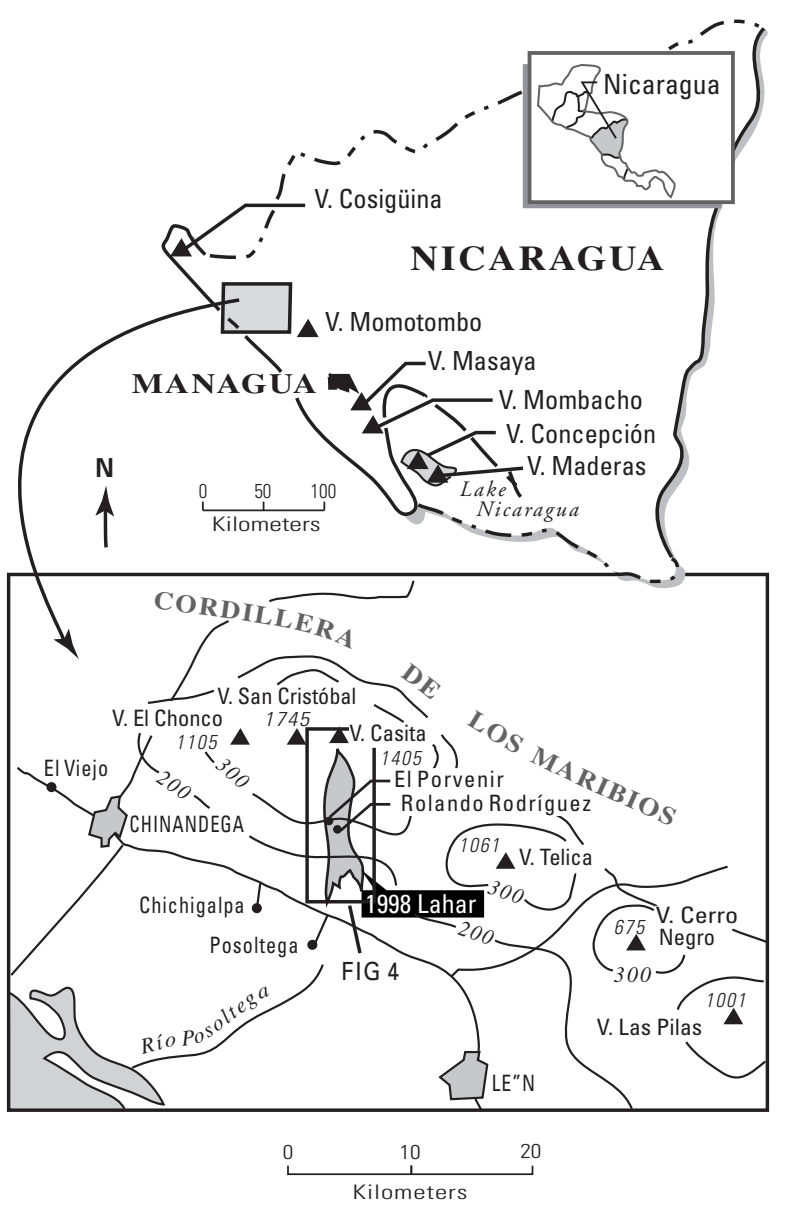

Figure 1. Locations of major cities and significant Quaternary volcanoes in Nicaragua including Casita volcano and schematic map showing the areal extent of the 1998 debris flow. 


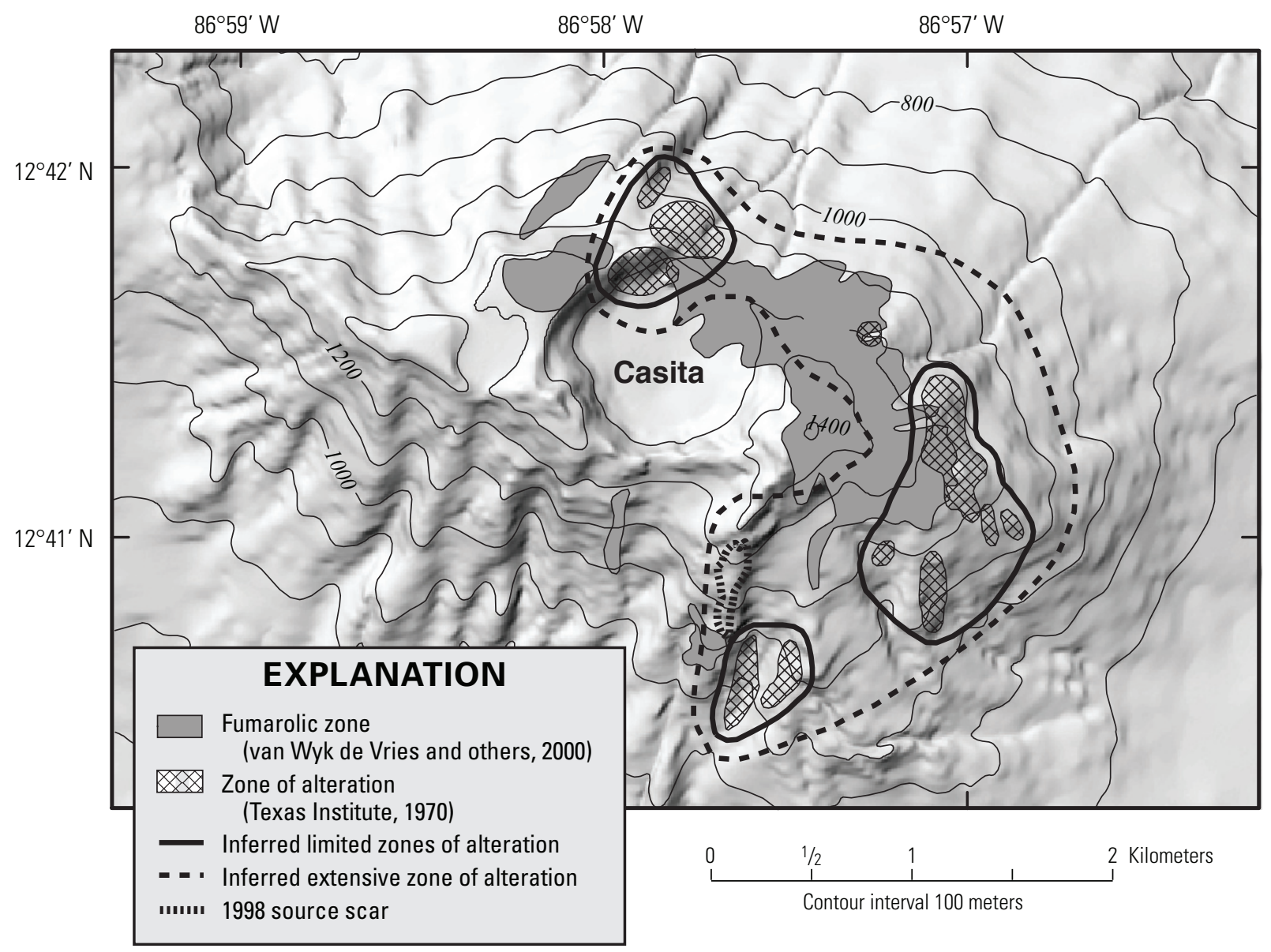

Figure 2. Shaded topographic map showing the edifice of Casita volcano and the distribution of fumarolic zones and areas of hydrothermal alteration.

When the Spanish first visited the Cordillera de los Maribios in AD 1524, they [1] reported that San Cristóbal volcano was erupting and "giving off visible flames." Apparently, the volcano remained active thoughout much of the $16^{\text {th }}$ century. The volcano erupted strongly in AD 1684 and again in AD 1685 [1]. Aside from fumarolic activity and minor ash emissions, a quiescent period of almost three centuries followed. Beginning in 1972, vigorous eruptions resumed [1]. Activity typically included sharp explosions, gas emissions, and ash fall to the south and west. The most recent eruptions of this type occurred in 1999 to 2000.

Population centers, especially to the south, occupy the aprons of the volcano complex and are at risk from phenomena common at stratovolcanoes. About $15 \mathrm{~km}$ southwest of San Cristóbal is the commercial and political center of Chinandega, which has a population of more than 50,000. El Viejo, also to the southwest, has a population of about 25,000 . Wind typically distributes ash and coarser particles ejected into the air (tephra) to the west or southwest of San Cristóbal volcano. During rainy periods, tephra on the steep slopes of the volcano can be mobilized to form debris flows (watery flows of mud, rock, and debris - also known as lahars when they occur on a volcano).

South of Casita, two towns with populations in the range of 5,000 to 15,000 inhabitants are Chichigalpa and Posoltega. Though Casita volcano has apparently not been active in historical time [1], or about the last 500 years, it has the potential to produce debris flows and debris avalanches that could inundate these nearby populated areas [2]. 
In late October and early November 1998, torrential rains of Hurricane Mitch caused numerous slope failures in Central America. The most catastrophic occurred at Casita volcano, on October 30, 1998. At Casita, five days of heavy rain triggered a 1.6-million-cubic-meter rock and debris avalanche that generated an 2- to 4million-cubic-meter debris flow that swept down the steep slopes of the volcano (figure 3 ). The debris flow spread out across the volcano's apron, destroyed two towns, and killed more than 2500 people [2]. In contrast to suggestions in initial accounts, the avalanche did not dam the upper drainages or impound water that later broke out to form the debris flow. Rather, it appears that the Casita debris flow evolved as the avalanche moved down slope [2].

On October 30, 1998, between 10:30 and 11:00 AM, residents south of Casita heard a roaring noise like helicopters or thunder. Some thought an earthquake was occurring. Three to five minutes thereafter, a wave of muddy debris 1.0 to $1.3 \mathrm{~km}$ wide and an average of $4.5 \mathrm{~m}$ deep destroyed all traces of two towns (figure 4 and frontispiece).

Observations by survivors indicate an enormous flood on the slopes of the volcano and a wall of mud on the volcano apron. A person on the volcano slopes saw a "black curtain of water with trees." On the apron of the volcano where the flow spread out, survivors describe the flow as--"an infernal wave of mud, rocks, and trees," or "enormous mass of mud." [2]. The debris flow moved about $10 \mathrm{~km}$ from its source. It also generated floods that moved an additional $10 \mathrm{~km}$ downstream, destroying roads and bridges and inundating homes.

In prehistoric time, Casita erupted explosively to form ash-fall deposits (tephra), debris avalanches, lava flows, and hot flowing mixtures of ash and rock (called pyroclastic flows). The chronology of activity at Casita is rather poorly known [1]. Its last documented eruption occurred 8300 years ago, and included a pyroclastic flow [2]. Tephra deposits exposed in the east crater suggest the possibility of subsequent eruptions. Work prior to Hurricane Mitch suggested that a part of the volcano's apron that included the area

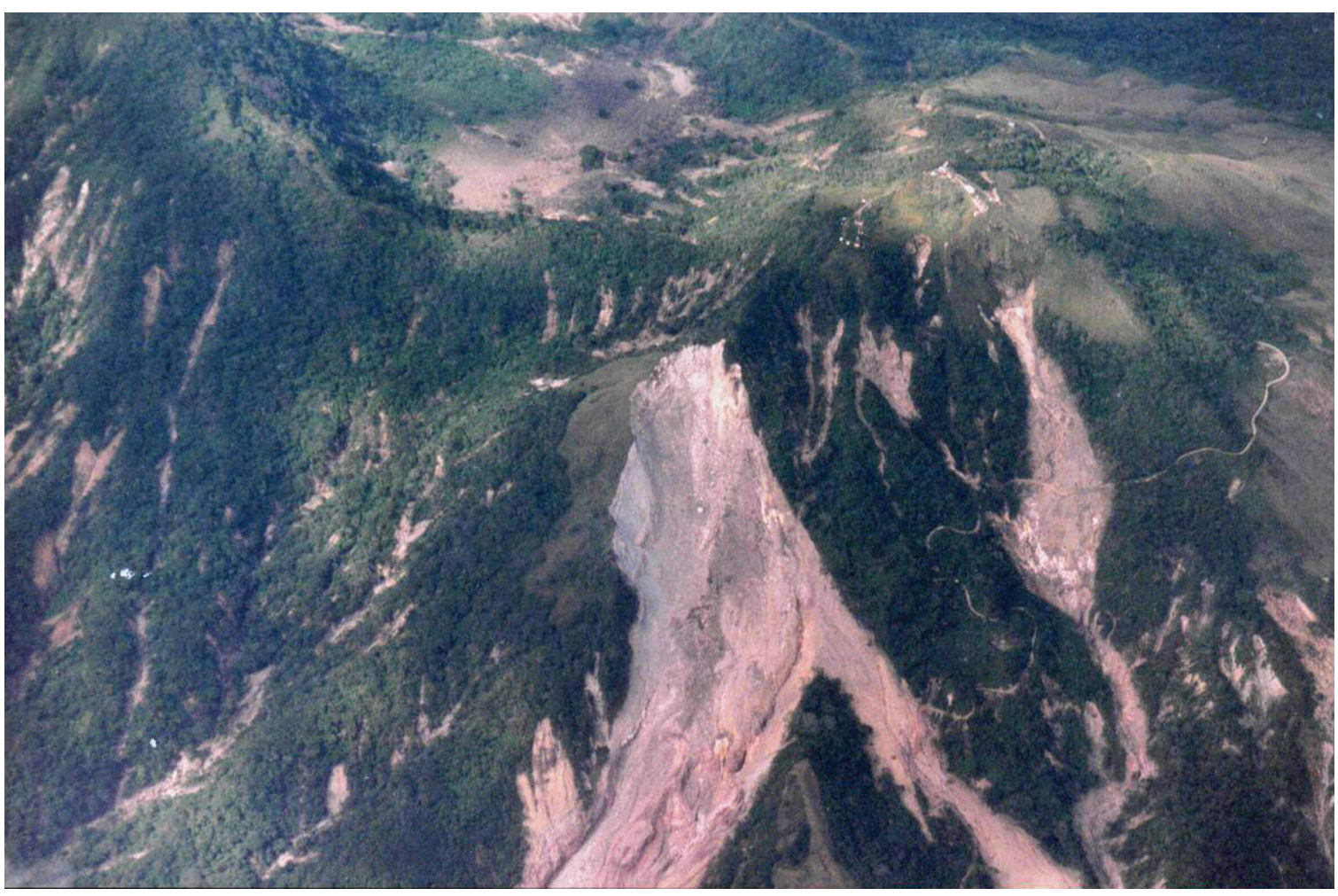

Figure 3. Aerial photograph of the upper southern slopes of Casita volcano showing the 1998 debris-flow scarp and numerous smaller scarps generated by Hurricane Mitch. 


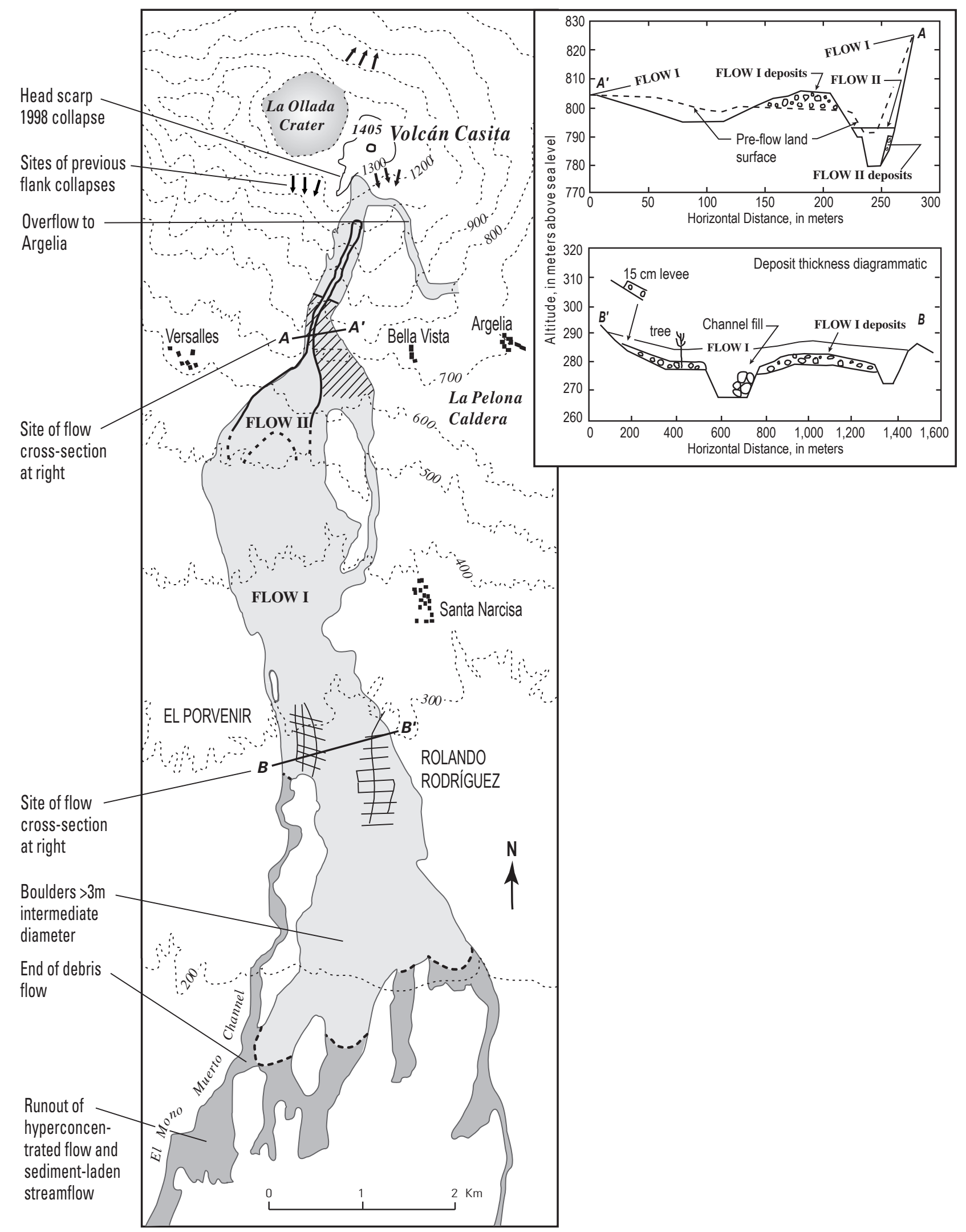

Figure 4. Topographic map and two cross-sections for the Casita, Nicaragua debris flow of 1998 (adopted from Scott and others, in press).. 
inundated during the 1998 event (plate 1) south of Casita was a lahar pathway [1]. Erosion during Hurricane Mitch revealed that at least three large lahars descended this pathway to distances of up to $10 \mathrm{~km}$ [2].

This report describes the hazards of landslides and lahars in general, and discusses potential hazards from future landslides and lahars at San Cristóbal and Casita volcanoes in particular. The report also shows, in the accompanying laharhazard-zonation maps, which areas are likely to be at risk from future landslides and lahars at Casita and San Cristóbal.

\section{DEBRIS AVALANCHES, LANDSLIDES, AND LAHARS}

Slope failure on a volcano can generate a rapidly moving landslide called a debris avalanche. Small-volume debris avalanches typically travel only a few kilometers from their source, but large-volume debris avalanches can travel tens of kilometers from their sources. Debris avalanches destroy everything in their paths and can leave deposits 10 meters thick or more on valley floors.

Lahars, also called mudflows and debris flows, are masses of mud, rock, and water that look much like flowing concrete. They commonly occur when water mobilizes large volumes of loose mud, rock, and volcanic debris. Alternately, landslides and debris avalanches sometimes incorporate enough water to form lahars. Lahars, like floods, inundate floodplains and structures in low-lying areas. They can travel many tens of kilometers down valleys at speeds of tens of kilometers per hour. Lahars destroy or damage everything in their paths through burial or impact. Lahars follow river valleys and leave deposits of muddy sand and gravel that can be several meters thick. They are particularly hazardous because they travel farther from a volcano than any other hazardous phenomenon except tephra, and they affect stream valleys where human settlement is usually greatest. In some instances, lahars clog channels or block tributaries so that water collects behind the blockage. The impounded water can spill over the blockage and generate floods that move down valley. Breaching of such blockages can occur within hours, months, or even years after impoundment.

Like floods, lahars range greatly in size. The amount of water and loose volcanic debris entrained determines lahar size. The smallest lahars occur most frequently (perhaps every few years), whereas the largest recur on the order of centuries to millennia. Eruptions can deposit millions of cubic meters of sediment into channels that when mixed with water during subsequent rains can cause lahars.

Landslides and lahars may occur long after the original eruption or other disturbance. Once lahars fill stream channels with sediment, the streams begin to erode new paths. The new stream channels can be highly unstable and shift rapidly as sediment is eroded and moved farther down valley. Also, because stream channels are clogged with sediment, they have less ability to convey water and thus are more susceptible to small-magnitude floods.

\section{GENESIS OF SLOPE FAILURES AND LAHARS AT CASITA DURING HURRICANE MITCH}

\section{Observations}

Examination of the headwall scarp at Casita indicates that the source area includes volcaniclastic (loose, unconsolidated volcanic) debris, fractured andesite lava, and hydrothermally altered rock (rock weakened by gases and fluids that circulate in the interior of volcanoes) (figure 5). The southern part (left third in figure 5) of the failure scarp is chiefly volcaniclastic debris ( $\mathrm{V}$ in figure 5). The central part of the scarp chiefly comprises fractured rock (II in figure 5) and secondary volcaniclastic material (III and V in figure 5) on top of relatively impermeable rock that is affected by hydrothermal alteration but relatively strong (IV in figure 5). The northern part (right third in figure 5) of the scarp comprises fractured rock (II in figure 5) on top of intensively hydrothermally altered, weakened rock (I in figure 5). The entire scarp area was dry one month after the 1998 rainy season, and there was no evidence of seeps or springs. The total failure volume was about $1,600,000$ cubic meters [2]. 
The slope failure produced debris-flow deposits, debris-avalanche to rock-avalanche deposits and talus. Nearest to source, talus deposits comprise angular boulders that fell off the steep scarp piecemeal (figure 5). A band adjacent to the talus comprises boulderrich avalanche debris (A and B, figure 5). A second band of debris ( $\mathrm{C}$ in figure 5 ) underlies the first and is avalanche debris that contains hydrothermally altered rock from the southfacing headwall (I in figure 5). Scattered debris and debris-flow deposits in the foreground ( $\mathrm{D}$ in figure 5) underlie the second band and overlie pre-Mitch volcaniclastic rocks. A generalized stratigraphic sequence from bottom to top is: 1. debris-flow deposits containing weak altered rock from I (figure 5); 2. debris-flow deposits containing altered rock from IV (figure 5);

3. debris-avalanche deposits with some altered rock ( $\mathrm{C}$ in figure 5); 4. fresh avalanche debris (A and $\mathrm{B}$, figure 5); and 5. talus.

\section{Genesis and downstream behavior}

We surmise that the combination of highly porous, permeable material overlying relatively impermeable and rotten rock played an important role in the initiation, magnitude, and subsequent behavior of the avalanche. Water would have readily infiltrated the fractured and volcaniclastic parts of the failure area but more impermeable altered rock at depth would have forced pore water outward toward the slope. If so the outward flow of pore water and the hydrothermally altered rock would have weakened resistance of the slope to failure.

Concentric fractures observed at the head of the 1998 scarp suggest that fractures predating the failure may also have existed at the head of the failure surface. If so their presence would have influenced failure initiation and location. During intense rainfall leading up to the slope failure these fracture probably filled with water

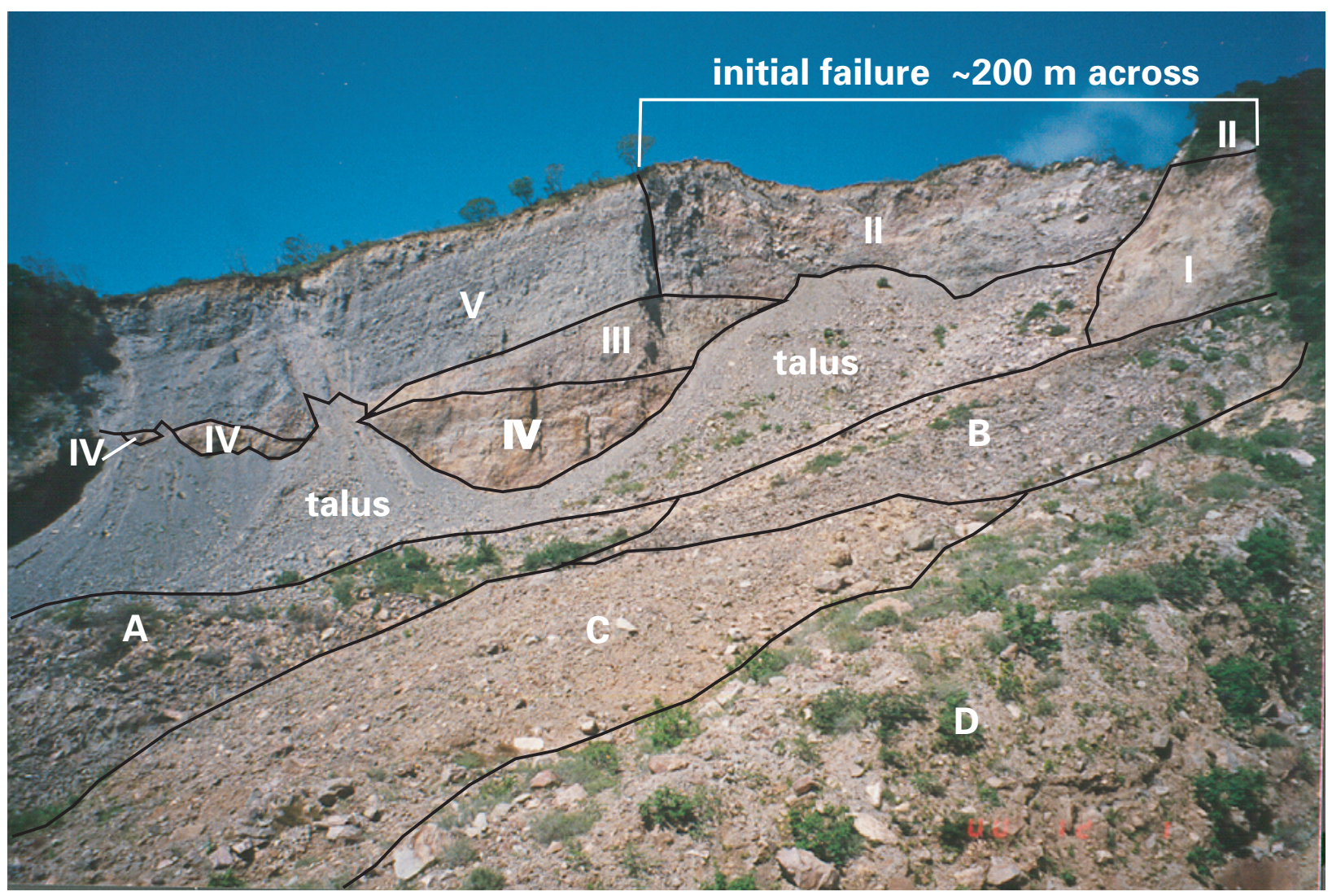

Figure 5. Photograph showing the scarp of the avalanche that generated the October 30, 1998 debris flow at Casita volcano. 
faster than they could drain. Such cracks, once lubricated with water, would have formed incipient, weak failure surfaces. Lastly, water added to the pre-failure mass during the rainy season and during the intense rainfall of the hurricane would have increased the weight of the material and added to the gravitational force favoring failure.

We infer that the failure proceeded as two or more successive failures. The initial failure came from the headward (north) part of the scarp (figure 5). It contained sufficient water and weakened hydrothermally altered rock (I in figure 5) that it disaggregated to form a waterrich debris flow that swept down the valley (D in figure 5). It also denuded the upper valley of vegetation, topsoil, and surface water. Because soils were water saturated and because of heavy rain the initial flow probably augmented its water content as it swept through the upper valley. Eyewitnesses described the initial flow as a watery torrent. It was this initial flow that destroyed the two towns and killed people down valley.

The second failure contained a significant amount of hydrothermally altered rock characteristic of the middle part of the scarp (especially IV of figure 5), and this material augmented the first debris flow or initiated a second one. As deposits indicate no hiatus between the debris flows, we infer that the debris-flow sequence was continuous. A third failure or a continuation of the second included rock-avalanche debris that now overlies hydrothermally altered rocks of the final phases of the debris flow (A and B in figure 5). This rock avalanche marks the end of debris flow in the upper headwaters of the drainage. Because evidence of a hiatus between elements of the rock avalanche and the debris flow is lacking we infer that the failure and flow sequence occurred continuously during an interval of seconds to a few minutes. Afterward, talus tumbled from all parts of the scarp.

Eyewitness accounts indicate that the initial flow was a watery torrent that rapidly incorporated sediment and vegetation as it flowed downslope. Lateral levees, poorly sorted deposits, and the behavior described in eyewitness accounts suggest that, upon reaching the Casita apron, the flow had picked up enough sediment to behave as a more typical sedimentrich debris flow, though it remained water rich. On the basis of its deposits, we infer that the primary Casita flow picked up enough additional debris to augment its volume by a factor of 2 to 3 .

The drainage that the Casita flow descended has acted as a lahar and debris-avalanche path in the past. Volcaniclastic deposits crop out along cut banks on the slopes of the volcano and along the stream banks of its apron. These deposits include lahars, debris avalanches, pyroclastic flows, and interbedded tephras. One organic rich deposit from the upper part of a sequence on the flank of the volcano has an age of about 8300 years before present (BP) [2].

Other landslides triggered at Casita during Hurricane Mitch are small, shallow, and typically derive from areas affected by fumaroles (figure 3). These failures expose small volumes of hydrothermally altered rock and caused small floods and debris flows.

\section{GENESIS OF LAHARS AND FLOODS AT SAN CRISTÓBAL DURING HURRICANE MITCH AND IN 2000}

Active, conical volcanoes, like San Cristóbal, were less affected by the intense rainfall of Hurricane Mitch than older, dissected, and somewhat hydrothermally altered volcanic edifices. On the steep upper slopes of volcanoes like Telica and San Cristóbal, the hurricane spawned sediment-rich floods, but, despite the lack of vegetation, not larger avalanches. The intense rainfall runoff eroded relatively straight, shallow radial drainages on the upper slopes of San Cristóbal (figure 6). Major landslides were most common on the steeper slopes of dissected older edifices like Casita, especially in areas variably affected by hydrothermal alteration processes (compare figures 3 and 6).

Rainfall runoff during Hurricane Mitch coalesced in drainages around the apron of San Cristóbal causing sediment-rich floods. Deposits from these floods are now present up to $10 \mathrm{~km}$ downstream of the edifice (plate 1). Deposits 
typically comprise loose sand and gravel that is stratified on a scale of centimeters. The deposits display prominent erosional boundaries between sets of low-angle strata.

On three occasions in May, 2000, small lahars occurred at San Cristóbal volcano. The volcano erupted during the dry season months of 1999 to 2000. As a result a small volume of loose ash collected on the upper slopes of the volcano. When the first rains occurred in May this loose sediment combined with water to form debris flows. These flows incorporated considerable extra sediment as they descended the steep slopes of the volcano. The flows ranged in size up to a maximum volume of 200,000 cubic meters. INETER was well prepared for these flows, and in collaboration with local authorities, was able to inform people potentially at risk from lahars. Lahars occurred on May 13, 17, and 19, 2000. No fatalities occurred during these events. By the end of May, rains had removed the ash on the upper slopes, and no further debris flows occurred through the remainder of the 2000 wet season.

\section{FUTURE LANDSLIDES AND LAHARS AT CASITA VOLCANO}

Casita can erupt explosively to produce widespread tephra falls, though the lack of historical volcanism suggests that the probability of explosive eruptions at Casita is less than at active Nicaraguan volcanoes like Masaya, Cerro Negro, Telica, and San Cristóbal. The ash and loose debris produced by an eruption would likely result in lahars when mixed with heavy precipitation during the rainy season. Small volcanic earthquakes, steam explosions, and deformation of the crater area would be likely to precede explosive eruptions at Casita volcano.

Because eruptions have been infrequent at Casita, landslides and debris flows during torrential rainstorms are the most likely threats to people and infrastructure [2]. These phenomena, like those at Casita during Hurricane Mitch and at Mombacho volcano in 1570, are most apt to occur during unusually intense and prolonged rain and are especially likely after long periods of rain toward the end of the rainy season.

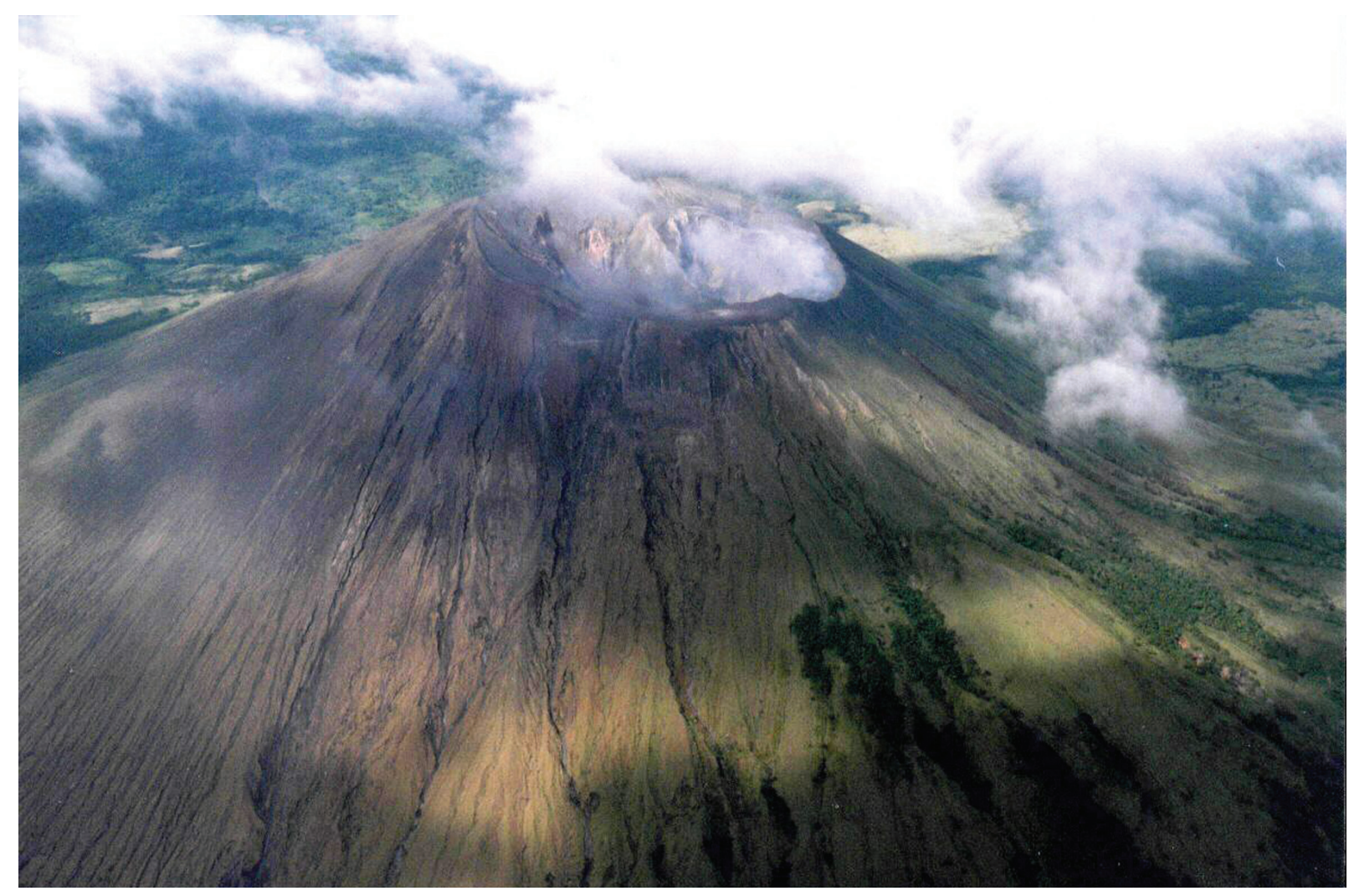

Figure 6. Photograph showing the edifice of San Cristóbal volcano from the northeast. 


\section{FUTURE LANDSLIDES AND LAHARS AT SAN CRISTÓBAL VOLCANO}

San Cristóbal volcano can erupt explosively to produce widespread tephra falls. Its present active period began in 1972 and continues to the present time. The historical record suggests that explosive eruptions at San Cristóbal can occur during active cycles and can produce at least ten times more voluminous tephras than those of 2000. The ash and loose debris produced by an eruption, especially a voluminous explosive eruption, would very likely cause lahars when mixed with heavy precipitation during the rainy season. Small volcanic earthquakes, steam explosions and deformation of the crater area would be likely to precede pyroclastic eruptions at San Cristóbal volcano

Because frequent eruptions are likely to replenish loose sediment in steep barrancas that incise the slopes of San Cristóbal volcano, landslides and debris flows during torrential rainstorms are the most likely threats to nearby people and infrastructure [1]. These phenomena, like those at Casita, are most apt to occur during intense rain. Because loose sediment can collect during eruptions or long dry periods and because water can easily mobilize that sediment, lahars are especially likely during the first rains after eruptions, at the beginning of the rainy season.

\section{Preliminary 3-D Slope-Stability Assessment of Casita and San Cristóbal Volcanoes}

In this section, we present a preliminary threedimensional (3-D) slope stability assessment aimed at identifying the areas on Casita and San Cristóbal volcanoes most likely to be affected by large landslides in the future. Large landslides that fail rapidly can transform into far traveling debris flows or lahars, particularly if the landslide materials are sufficiently saturated with pore water and contain small amounts of clay [3]. The large Casita landslide had a source volume of about 1.6 million $\mathrm{m}^{3}$ and it increased its volume by a factor of 2 to 3 as it moved downslope [2]; therefore, our analyses focus on potential large landslides ranging in volume from 500,000 to 5,000,000 cubic meters. Our analyses do not directly address the potential occurrence of smaller landslides, nor do they address the potential for very large sector collapses. Here, we examine potential 3-D slope instability localized by steeper ground surface topography and weaker rock strengths [4]. Prolonged or intense rainfall, strong earthquake shaking, or volcano unrest could trigger such ground failures. Users should be aware that we have not simulated all hazardous landslide scenarios.

Because of uncertainties in the 3-D distribution of rock strength at Casita volcano, we examined three plausible scenarios: (1) an edifice with uniform, somewhat altered rocks, (2) an edifice with three small zones of highly altered (weaker) rock near mapped fumarolic areas, and (3) an edifice with a more extensive highly altered (weaker) zone encompassing mapped fumarolic areas [4].

The inferred zones of altered rock for scenarios 2 and 3 are shown in Figure 2. Scenario 3 provides a more conservative, worst-case scenario with respect to large slope failures. This scenario also includes the source scar of the massive Hurricane Mitch landslides within the zone of highly altered (weaker) rocks. We observed altered rocks in the scar of this slide, even though previous mapping had not identified this as a fumarolic area. In all cases we assume that alteration extends to depths below potential failure surfaces. The San Cristóbal edifice is modeled as uniform, unaltered, relatively strong rocks in all scenarios.

Scenario 1 shows predicted 3-D slope stability using uniform edifice strengths (figure 7). In this scenario, much of the upper edifice of San Cristóbal shows moderate potential for instability; the steep, eastern slope is slightly less stable than the remainder of the upper edifice. On the edifice of Casita, two areas on the west inside crater wall, and one area on the upper southwest flank have reduced stability. These areas are steep. Scenario 2 shows the predicted stability using limited zones of greater alteration and weaker rocks (figure 8), and predictions show stability is lower near the more altered zones. However, the southern and eastern more altered zones are on gentler slopes and are still relatively stable. The northern altered zone encompasses some steeper 


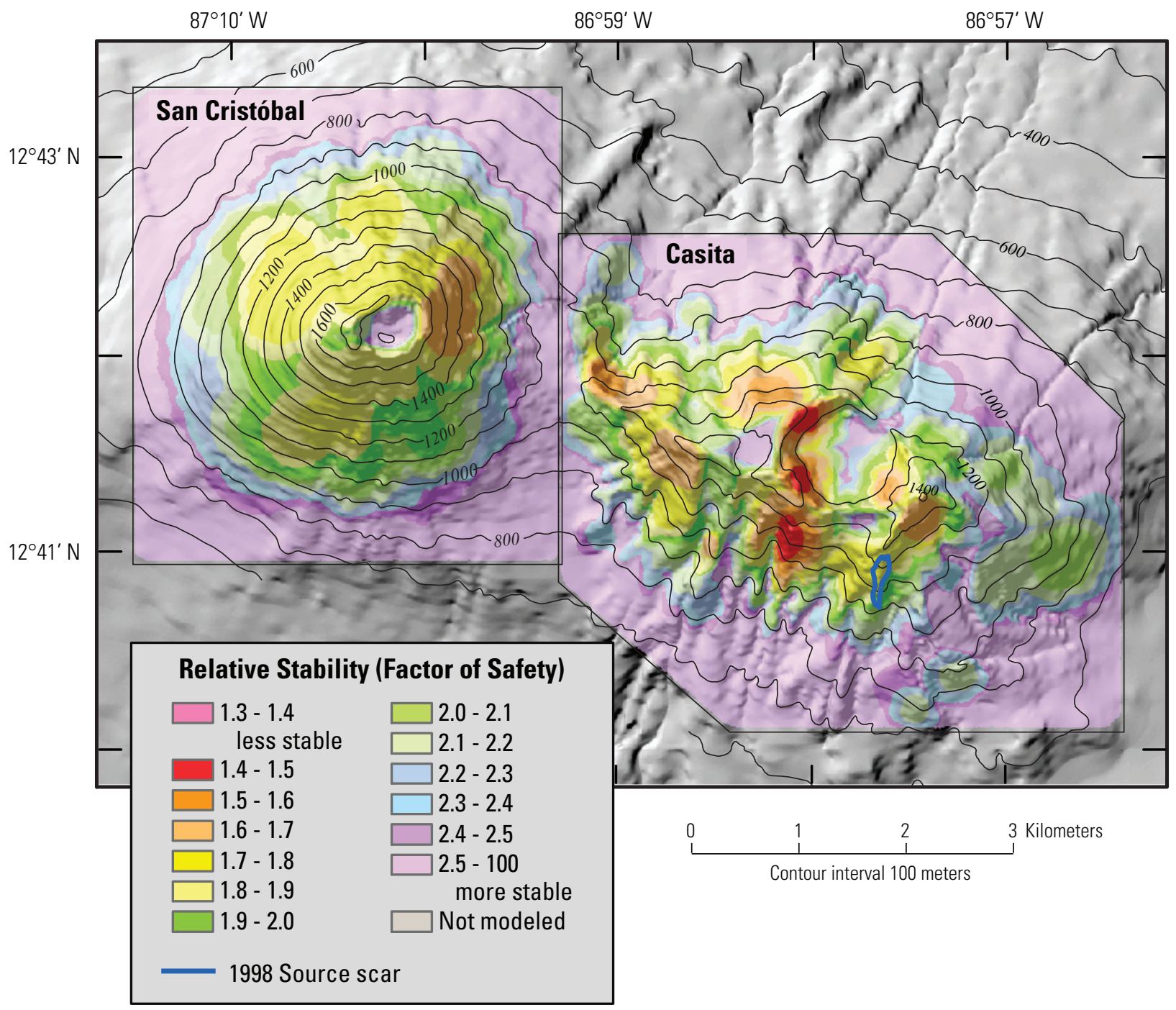

Figure 7. Shaded topographic map of San Cristóbal and Casita volcanoes showing predicted 3-D slope stability using scenario 1, uniform relatively strong rocks in the San Cristóbal edifice and uniform moderately weak rocks in the Casita edifice.

terrain, and is significantly less stable in this case than in the uniform scenario. Scenario 3 shows the predicted stability using an extensive zone of greater alteration (figure 9). Here, relatively unstable areas occur on the northeast and southeast flanks, in addition to the unstable areas identified in scenarios 1 and 2 .

These results suggest uniform potential instability for large landslides on the San Cristóbal edifice, but variable, and in places greater potential instability on the Casita edifice. The source scar for the massive failure triggered by Hurricane Mitch is located on the southeast flank. This location corresponds well with an unstable area predicted in scenario 3. Many of the smaller failures on Casita during Hurricane Mitch occurred in areas on the southwest flank and the west inner crater wall predicted to be unstable in all three scenarios. Overall these results indicate that scenario 3 with an extensive altered zone is an appropriate tool for predicting the future locations of possible large (ranging in volume from 500,000 to $5,000,000 \mathrm{~m}^{3}$ ) slope failures on Casita volcano. 


\section{LAHAR-HAZARD ZONATION AT CASITA AND SAN CRISTÓBAL VOLCANOES}

The accompanying lahar-hazard-zonation maps (plates 2 and 3) show areas that could be affected by future lahars at or near Casita and San Cristóbal volcanoes. Individual lahars typically affect only part of a hazard zone. The location and size of an affected area will depend on local conditions, like the volume of material involved, and the character of the eruption, if any.

Potentially hazardous areas around Casita and San Cristóbal volcanoes are delineated as laharhazard zones. Lahar-hazard zones are further subdivided on the basis of their relative degree of hazard. Hazard-zone boundaries derive from three main factors. First, the magnitudes of lahars known to have occurred at the volcano, as inferred from historical accounts and prehistoric deposits, allow delineation of a range in size of past events. Both areal extent and volume of past events are considered. Second, an empirical model calibrates lahar-inundation limits on the basis of lahars of known volume that have occurred at other volcanoes [5]. Third, we apply our experience and judgment derived from past experience with events of a similar nature at other volcanoes.

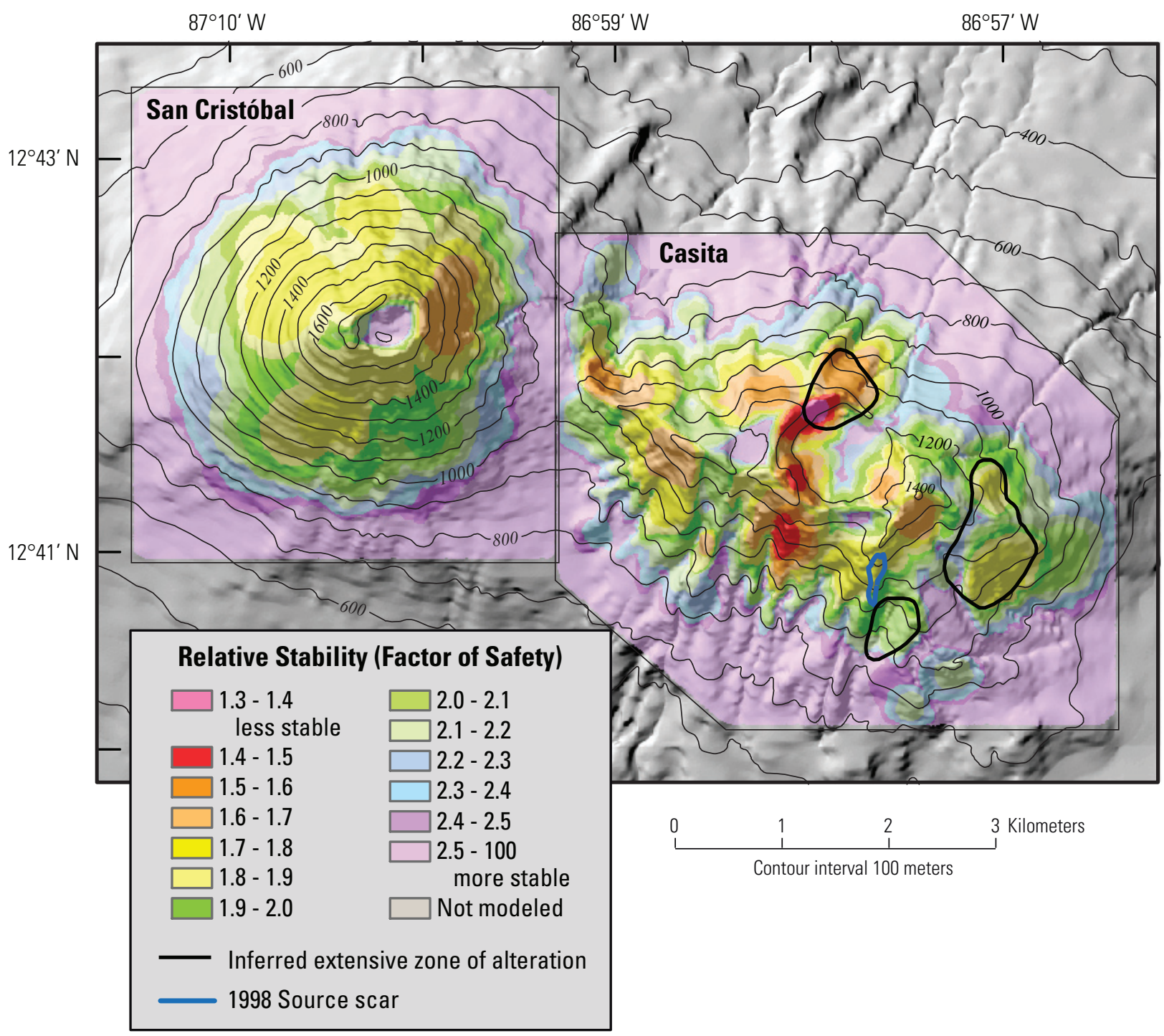

Figure 8. Shaded topographic map of San Cristóbal and Casita volcanoes showing predicted 3-D slope stability using scenario 2, assuming three limited, highly altered, weak zones in the Casita edifice. 
Although sharp boundaries delineate each hazard zone, the limit of the hazard does not end abruptly at the boundaries. Rather, the hazard decreases gradually as distance from the volcano increases and decreases rapidly with increasing elevation above valley floors. Areas immediately beyond distal hazard zones are not free of risk because the hazard limits can only approximately be located, especially in areas of low relief. Many uncertainties about the source, size, and mobility of future lahars preclude precise location of the hazard-zone boundaries. Users of our hazard map should be aware that we have not simulated all hazardous landslide and lahar scenarios.

\section{Lahar-hazard zonation map for Casita volcano}

The edifice of Casita volcano is steep, incised, and partly affected by hydrothermal weakening of the rock. For this report, we selected prominent channels directed toward populous areas in order to define the most significant zones of inundation from lahars of various volumes. Other channels for which we have not modeled lahar inundation are not necessarily devoid of lahar hazard, but are less likely to spawn lahars. Landslides and lahars from other unmapped channels could also threaten life and property.

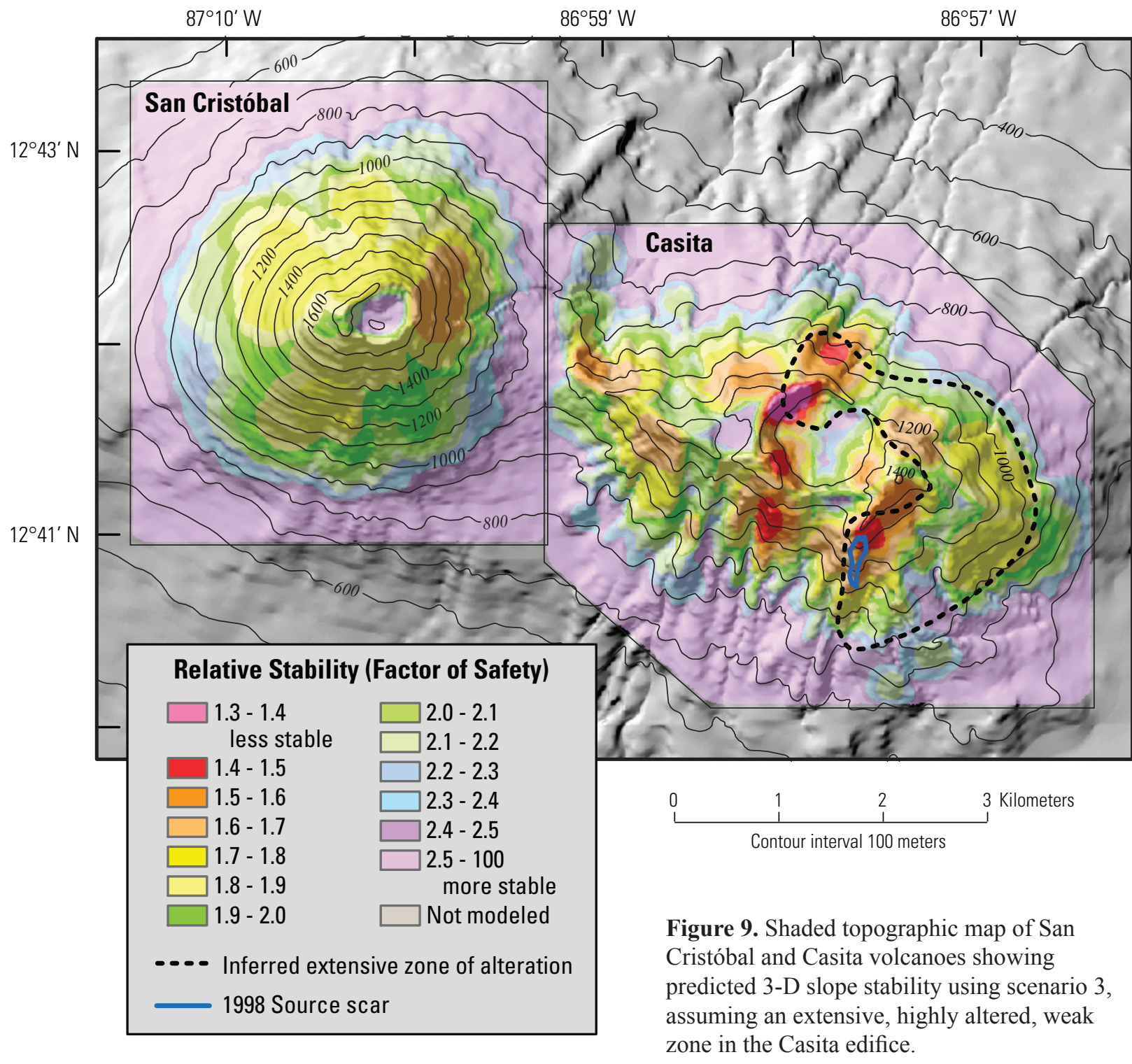


An automated empirical technique calibrated with data from other volcanoes [5] estimates potential areas of inundation from lahars of various volumes. For each channel analyzed, we define four nested hazard zones that depict anticipated inundation by hypothetical "design" lahars ranging in volume from 1 to 8 million cubic meters. These largest design volumes reflect all lahar materials, including landslide source volumes, scoured bedrock, and entrained channel debris. We estimate that these volumes represent the largest probable lahars generated on the steep slopes of Casita volcano (plate 2) [5]. The intermediate and smallest design lahars are more typical lahar volumes. Lahars of the largest sizes have occurred historically at Casita and would be possible after an eruption, during severe rainstorms, or during large earthquakes.

Large lahars ( 8 million cubic meters) are less likely to occur than small lahars ( 1 million cubic meters). Thus, the nested lahar-hazard inundation zones show that the likelihood of lahar inundation decreases as distance from the volcano and elevation above the valley floors increases. At Casita during Hurricane Mitch, dozens of small lahars and a couple intermediate-size ones occurred (figure 3 ), in addition to the notable one that destroyed El Porvenir and Rolando Rodriguez. Similarly, lahars of all designated sizes could form on the volcano's slopes if unusually intense rainstorms recur. An intense storm, like Hurricane Mitch, would not invariably trigger lahars as large as the one that occurred at Casita in 1998. Smaller lahars may occasionally result from heavy rains that normally occur each year during the rainy season of May to November.

Lahars most probably will originate in the proximal lahar-hazard zone on the edifice of Casita (plate 2) and are most likely to initiate on steep slopes or areas where the rock is weakened by hydrothermal alteration (figures 7 to 9). Our stability analysis shows that steep slopes are more likely to fail and generate lahars than gentle slopes. Furthermore, the weakest rock on the edifice is altered by hydrothermal fluids and gases of the fumarolic zone and is considerably more apt to fail than fresh rock (compare relative stabilities in figure 7 to those in figures 8 and 9). Scenario 3 (figure 2) delineates the most conservative estimate of weakened rock on the edifice of Casita, and determines areas of diminished relative slope stability on the northern, eastern, and southeastern flanks of the edifice (figure 9). Depending on the lahar volume modeled, lahar-hazard zones extend 6 to $10 \mathrm{~km}$ beyond the proximal zone (plate 2). The ridge-like morphology of the proximal summit area dictates lahar-hazard zones that extend mainly to the south or to the north-northeast. In both directions beyond the steep proximal slopes, lahar travel distances are likely to be similar in principal drainages because local drainage topography is similar in these two directions. Beyond the margins of the nested lahar-hazard zones is an area that might be affected by dilute lahar runouts and floods. This hazard zone extends an additional $10 \mathrm{~km}$ downstream or about $20 \mathrm{~km}$ from the proximal zone.

\section{Lahar-hazard zonation map for San Cristóbal volcano}

The edifice of San Cristóbal volcano is steep, symmetrical, and cut by radial gulleys. The rock that comprises the edifice appears relatively strong and not noticeably weakened by alteration. For this report, we selected prominent channels directed toward populous areas in order to define the most significant zones of inundation from lahars of various volumes. Other channels for which we have not modeled lahar inundation are not necessarily devoid of lahar hazard. Landslides and lahars from other unmapped channels could also threaten life and property.

As in the previous section, an automated empirical technique calibrated with data from other volcanoes [5] estimates potential areas of inundation from lahars of various volumes. Again accounting for all sediment sources, we identify a likely maximum lahar volume. For each channel analyzed, we define four nested hazard zones that depict anticipated inundation by hypothetical "design" lahars ranging in volume from 125,000 to 1 million cubic meters. The largest design lahar ( 1 million cubic meters) reflects our estimate of the largest probable lahar generated on the steep slopes of San Cristóbal volcano (plate 3) [5]. The intermediate and smallest design lahars (125,000 and 250,000 cubic meters) are more typical lahar volumes. 
Lahars of the largest sizes would be likely after large eruptions, during severe rainstorms, or during large earthquakes.

As in the previous section, the nested laharhazard inundation zones show that the likelihood of lahar inundation decreases as distance from the volcano and elevation above the valley floors increases. Lahars most probably will initiate from the proximal lahar-hazard zone (plate 3 ) and are most likely to derive from the steepest slopes (scenario 1, figures 2 and 7). Depending on the volume modeled, lahar-hazard zones extend up to $6 \mathrm{~km}$ beyond the proximal zone (plate 3 ). The conical morphology of the San Cristóbal requires that lahar-hazard zones extend radially outward except where obstructed by topographic barriers to the northwest and east. Beyond the steep proximal slopes, lahars will travel equal distances because of the radial symmetry of drainage topography. Beyond the margins of the nested lahar-hazard zones is an area that might be affected by dilute lahar runouts and floods. This hazard zone extends an additional $5 \mathrm{~km}$ downstream or about $10 \mathrm{~km}$ from the proximal zone.

\section{HAZARD FORECASTS AND WARNINGS}

It is difficult to predict the precise timing and location of landslides and lahars triggered by earthquakes or torrential rains. Hazardous conditions that favor formation of landslides and lahars include heavy rainfall, saturated soil and steep slopes. Forecasts for very heavy rainfall can serve as indicators of conditions favorable for landslides and lahars. The steep, incised edifice of Casita volcano is variably affected by hydrothermal weakening of its rock and especially susceptible to avalanche-triggered lahars caused by heavy precipitation or tectonic earthquakes.

San Cristóbal volcano will erupt again, and it is likely to deposit tephra on its flanks. Subsequent erosion of that tephra can generate lahars similar to or larger than those that have occurred in historical time. In this case, the eruption of the volcano can serve as a warning that conditions are favorable for lahar formation, and the distribution of tephra fall can indicate which flanks are more likely to be affected. However, government officials and the public need realize that potentially lethal events can occur in the lahar-hazard zones with little or no warning.

\section{PROTECTING COMMUNITIES AND CITIZENS FROM LAHAR HAZARDS}

Communities and citizens must plan ahead to mitigate the effects of future landslides and lahars from Casita and San Cristóbal volcanoes. Long-term mitigation efforts might include using information about lahar and landslide hazards contained in plates 1-3 when making decisions about land use and siting of critical facilities and development. Future development should avoid areas judged to have an unacceptably high risk.

Lahar-hazard zones depicted on the map will be affected within a few minutes to about one hour after the onset of a lahar depending on distance from the source. Within 8 to $10 \mathrm{~km}$ of the volcano, lahars may arrive too quickly to provide effective warning. Therefore, citizens must learn to recognize for themselves hazardous conditions that favor formation of landslides and lahars. Conditions that favor lahars include volcanic eruptions, first rains after eruptions, and unusually intense or prolonged rainfall. Generally, the beginning of the rainy season, and the latter part of the rainy season, when the ground is saturated with water are the most common periods that lahars occur. An approaching lahar may sound like an approaching locomotive or thunder and commonly causes the ground to vibrate or shake. People should seek high ground immediately on noticing such warning signals.

Because landslides and lahars can occur without warning, suitable emergency plans for dealing with them should be made in advance. Although it is uncertain when landslides and lahars will occur again at Casita and San Cristóbal 
volcanoes, public officials need to consider issues such as public education, communications, and evacuations as part of a response plan. Emergency plans already developed for floods may apply to some extent, but will need modifications.

Knowledge and advance planning are the most important factors for dealing with landslide and lahar hazards. Especially important is a plan of action based on the knowledge of relatively safe areas around homes, schools, and workplaces. Lahars pose the biggest threat to people living or working along channels that drain Casita and San Cristóbal volcanoes. The best strategy for avoiding a lahar is to move to the highest possible ground. A safe height above river channels or lahar pathways depends on many factors including the size of the lahar, distance from the volcano, and shape of the valley. For inhabitants in low-lying areas, a map showing the shortest route to high ground would be helpful. Landslides and lahars from Casita and San Cristóbal volcanoes will happen again, and the best way to cope with these events is through advance planning.

\section{REFERENCES}

Carrasco-Núñez, G., Vallance, J.W., and Rose, W.I., 1993, A voluminous avalanche-induced lahar from Citlaltepetl volcano, Mexico: Implications for hazard assessment: Journal of Volcanology and Geothermal Research, v. 59, p. 35-46.

Hazlett. R.W., 1977, Geology and hazards of the San Cristóbal volcanic complex, Nicaragua: Ph.D. Thesis, Dartmouth College, 212 p.

Hoek, E., and Bray, J.W., 1981, Rock slope engineering: London, Institute of Mining and Metallurgy, $358 \mathrm{p}$.

Iverson, R.M., Reid, M.E., and LaHusen, R.G., 1997, Debris-flow mobilization from landslides: Annual Review of Earth and Planetary Sciences, v. 25, p. 85-138.

Iverson, R.M., Schilling, S.P., and Vallance, J.W., 1998, Objective delineation of lahar-hazard zones downstream from volcanoes: Geological Society of America Bulletin, v. 110, p. 972-984.
Kerle, N., in press, Volume estimation of the 1998 flank collapse at Casita volcano, NicarCasita-a comparison of photogrametric and conventional techniques: Earth Surface Processes and Landforms

Kerle, N., and van Wyk de Vries, B., 2001, The 1998 debris avalanche at Casita volcano-investigation of structural deformation as the cause of slope instability using remote sensing: Journal of Volcanology and Geothermal Research, v. 105, p. 43-63.

Lopez, D.L., and Williams, S.N., 1993, Catastrophic volcanic collapse; relation to hydrothermal processes: Science, v. 260, p. 1794-1796.

Mooser, F., Meyer-Abich, H., and McBirney, A.R., 1958, Catalogue of the active volcanoes of the world including solfatara fields, Part VI, Central America: International Volcanological Association, Napoli, Italy, 146 p.

Oviédo y Valdés, G.F. de, 1855, Historia general y natural de las Indias: Madrid, v. 4 p. 65-91.

Reid, M.E., Christian, S.B., and Brien, D.L., 2000, Gravitational stability of three-dimensional stratovolcano edifices: Journal of Geophysical Research, v. 105, p. 6043-6056.

Reid, M.E., Sisson, T.W., and Brien, D.L., 2001, Volcano collapse promoted by hydrothermal alteration and edifice shape, Mount Rainier, Washington: Geology, v. 29, p. 779-782.

Scott, K.M., Vallance, J.W., Kerle, N, Macías, J.L., Strauch, W., and Devoli, G., in press, Catastrophic, precipitation-triggered lahar at Casita volcano, NicarCasita-occurrence, bulking and transformation: Earth Surface Processes and Landforms.

Siebert, L., 1984, Large volcanic debris avalanches: characteristics of source areas, deposits, and associated eruptions: Journal of Volcanology and Geothermal Research, v. 22, p. 163-197.

Sheridan, M.F., Bonnard, C., Carreno, R., Siebe, C., Strauch, W., Navarro, M., Calero, J.C., and Trujillo, N.B., 1999, Report on the 30 October 1998 rockfall/debris avalanche and breakout flow of Casita volcano, NicarCasita, triggered by Hurricane Mitch: Landslide News, n. 12, p. 2-4.

Texas Instruments, 1970, Reporte final, Proyecto de Recursos Geotermicos - Etapa Una. Parte 2, Geologia Regional, Manifestaciones Termales de Nicaragua Occidental. Informe elaborado para el Gobierno de Nicaragua, Ministerio de Economia, Industria y Comercio, 22p. 
van Wyk de Vries, B., Kerle, N., and Petley, D., 2000, Sector collapse forming at Casita volcano, Nicaragua: Geology, v. 28, p. 167-170.

Voight, B., and Elsworth, D., 1997, Failure of volcano slopes: Geotechnique, v. 47, p. 1-31.

Watters, R.J., and Delahaut, W.D., 1995, Effect of argillic alteration on rock mass stability, in Haneburg, W.C., and Anderson, S.A., eds., Clay and shale slope instability, Volume X, Geological Society of America Reviews in Engineering Geology, p. 139-150.

Watters, R.J., Zimbelman, D.R., Bowman, S.D., and Crowley, J.K., 2000, Rock mass strength assessment and significance to edifice stability, Mount Rainier and Mount Hood, Cascade Range volcanoes: Pure and Applied Geophysics, v. 157, p. 957-976.

\section{ADDITIONAL SUGGESTED READING}

Blong, R.J., 1984, Volcanic hazards: Orlando, Florida, Academic Press, 424 p.

Tilling, R.I., ed., 1989, Volcanic hazards: Short course in geology, v. 1, Washington, D.C., American Geophysical Union, $123 \mathrm{p}$.

Vallance, J.W. 2000, Lahars: in Sigurdsson, H., Houghton, B., McNutt, S., Rymer, H., and Stix, J., Encyclopedia of volcanoes, San Diego, Academic Press, p. 601-616. 


\section{END NOTES}

[1] The general geology and history of volcanism is presented in Mooser and others (1958) and Hazlett (1977). Hazlett (1977) also presents a basic volcano-hazard assessment of the San Cristóbal volcanic complex. Oviédo y Valdés (1855) gives reference to some of the original Spanish accounts of volcanism at San Cristóbal.

[2] Information about the Casita flow derives from Sheridan and others (1999), Kerle and Van Wyk de Vries (2001), Kerle (in press), and Scott and others (in press). Using digital elevation models (DEM's) from before and after the landslide, Kerle and Van Wyk de Vries (2001) and Kerle (in press) estimate its volume at $1,600,000 \mathrm{~m}^{3}$.

[3] Carrasco-Nuñez and others (1993), in their study of an avalanche-induced lahar at Pico de Orizaba, Mexico, suggest that hydrothermal clay in a debris avalanche makes it more likely to transform into a lahar. Iverson and others (1997) indicate that clay in the matrix of debris flows may enhance their mobility.

[4] To assess potential 3-D slope instability, we use geotechnical limit-equilibrium methods (Reid and others, 2000). Although volcano slope instability can result from a wide variety of factors (Voight and Elsworth, 1997), we focus on two factors known to influence gravitational instability - edifice shape and rock strength. The applicability of stability results from our approach can be limited by a variety of factors, such as poor quality topographic data or uncertainties in the subsurface distribution of rock strength, mode of failure (one mass or many pieces), and failure trigger (elevated pore-fluid pressures, earthquake shaking, etc.). Nevertheless, this approach produced very useful results in a 3-D slope stability assessment of Mount Rainier volcano in Washington State, USA (Reid and others, 2001) where detailed geologic and geophysical information, along with a well documented debris-flow history, were available.
We search for unstable regions throughout Casita and San Cristóbal volcanoes by calculating the stability of millions of different spherical potential failure surfaces intersecting each edifice. The volcanoes are represented by a 10 -meter digital-elevation model (DEM). This DEM is based on pre-Hurricane Mitch topography prepared for this report. We assume that average shear resistance, $\tau$, acting on a potential failure surface is given by the Coulomb failure rule, $\tau=c+$ On $\tan \phi$, where $c$ is cohesion, $\sigma_{n}$ is total normal stress acting on the failure surface, and $\phi$ is the angle of internal friction of the rock. Gravitational stresses result from rock unit weight, $\gamma$, and topography. Summing the vertical forces and rotational moments acting on each potential failure surface, we calculate a factor of safety, $F$, for that surface (Reid and others, 2000). Instability is reflected in values of $F<1$; low values of $F$ indicate a propensity for collapse. We then produced maps portraying the relative stability of different parts of the edifice by plotting the lowest $F$ value of any potential failure surface underlying each point of the DEM.

Stratovolcano edifices can be extremely heterogeneous, containing rocks or unconsolidated materials with a wide range in strength. For our preliminary 3-D stability analyses, we assume that similar rock strengths apply over large areas, on a scale similar to large landslide failure surfaces. Rockslides can initiate along weak structural discontinuities, such as joints or fractures. However, the sliding surface of a large failure ignores local small features, and may be arcuate if discontinuities are closely spaced (Hoek and Bray, 1981). Such an approach provided good results at Mount St. Helens (Reid and others, 2000) and Mount Rainier (Reid and others, 2001). Overall, the steeper flanks and younger deposits of San Cristóbal volcano suggest relatively stronger rocks than those of Casita. The more dissected edifice and greater proportion of hydrothermally altered rocks exposed at the surface of Casita suggest rocks that are relatively weaker than those at San Cristóbal. 
Hydrothermal alteration from degassing or circulating thermal fluids within a volcano can reduce the mechanical shear strength of rock (Watters and D elahaut, 1995; Watters and others, 2000) and contribute to volcano edifice instability (Lopez and Williams, 1993; Siebert, 1984). We observed hydrothermally altered rocks exposed in recent landslide scars, including the large failure scar on Casita volcano, however vegetation obscures direct observation of the degree of alteration over much of the edifice. Areas near modern fumarolic activity on parts of the Casita edifice are likely to be hydrothermally altered, and may include rocks with significantly reduced strengths. Figure 2 shows the distribution of mapped fumarolic areas on Casita volcano from two published reports (Texas Instruments, 1970; van Wyk de Vries and others, 2000). Note that, although the fumarole distributions vary somewhat between the reports, modern activity appears focused on the eastern half of the edifice.

Given broad differences in the degree of hydrothermal alteration affecting the two edifices, we divided rocks into three groups based on the degree of alteration: (relatively fresh rocks $\left(\phi=38^{\circ}, c=140 \mathrm{kPa}\right.$, and $\gamma=$
$24 \mathrm{kN} / \mathrm{m}^{3}$ ), representing the San Cristóbal edifice, (2) somewhat altered rocks $\left(\phi=35^{\circ}\right.$, $c=120 \mathrm{kPa}$, and $\gamma=23 \mathrm{kN} / \mathrm{m}^{3}$ ), representing the bulk of the Casita edifice, and (3) more highly altered rocks $\left(\phi=30^{\circ}, c=85 \mathrm{kPa}\right.$, and $\gamma=20 \mathrm{kN} / \mathrm{m}^{3}$ ), representing the fumarolic areas on Casita. Rock properties were estimated using values derived from field and laboratory shear tests on small specimens of volcanic rocks (Watters and Delahaut, 1995; Watters and others, 2000).

[5] We constructed lahar-hazard zones by choosing design-lahar volumes of $1,000,000$; $2,000,000 ; 4,000,000$, and 8,000,000 cubic meters for Casita and 125,000, 250,000, 500,000 , and 1,000,000 cubic meters for San Cristóbal. We then modeled a lahar for each volume using the repeatable empirical model and digital cartographic technique described in Iverson and others (1998). The model requires the choice of a reasonable range of lahar volumes for each volcano. It then uses these volumes to compute average cross-sectional areas and areas of inundation for each modeled lahar. The GIS based computer program, LAHARZ (Iverson and others, 1998) then calculates the extent of inundation downstream in each drainage that heads on the volcano.

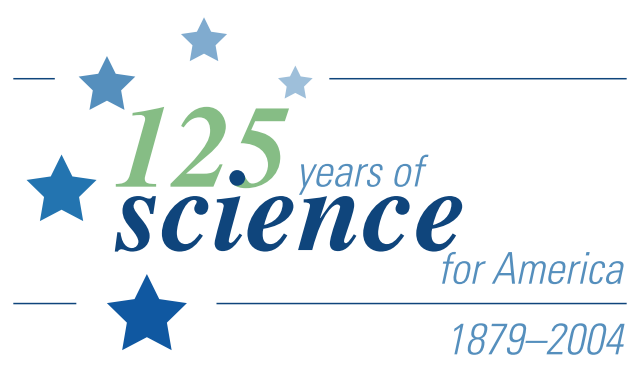

